\title{
Labour Market Issues in Pakistan: Unemployment, Working Conditions, and Child Labour
}

\author{
SABUR GHAYUR
}

\section{INTRODUCTION}

Pakistan's labour market is showing its inability to continue the past trend of labour absorption. Generation of additional work opportunities commensurate with labour supplies, increasing by over 3 percent annually, has emerged as the most formidable challenge of the nineties. The labour market is presently confronted with the twin menace of unemployment and underemployment. Although, the rate of unemployment has not as yet assumed serious proportions, the worrying aspect of this 5 percent unemployment is its concentration amongst the youth, and educated and trained. The under-utilisation of manpower, however, is manifested in the form of under-employment. There are more than a-tenth of the employed who find their work unable to keep them busy for 35 hours a week [FBS (1994)]. Further, those employed a-quarter of them find their employment income only meeting half of the subsistence requirements, while a similar proportion find their employment income barely managing to meet the subsistence requirements [NMC (1989)]. Lesser productive and low remunerative work opportunities is thus emerging as the major characteristic of the labour market in Pakistan.

The situation in the labour market is serious on yet another account. The working conditions of those lucky found employed, by and large, are not satisfactory, rather they are deplorable. Long working hours and poor working conditions are the normal features of a significant number of work places. A number of them also carry occupational safety and health hazards. The situation is compounded further by observing denial of basic rights to a large number of workers. ${ }^{1}$ Existing labour laws require reforms and whatever exist face implementation lacunas. Further discomforting is the fact that the trade union movement in Pakistan stands divided and fragmented. ${ }^{2}$

Sabur Ghayur is Deputy Resident Representative and Programme Coordinator, Pakistan office of the Friedrich-Ebert-Stiftung, Islamabad.

Author's Note: This is an improved and shorter version of the paper entitled "Labour Market in Pakistan: Existing Situation, Issues and Emerging Pressures" presented in the Regional Conference on: "Labour Market and Industrial Relations in South Asia," organised by the Indian Society of Labour Economists, Institute of Applied Manpower Research and Indian office of the Friedrich-Ebert-Stiftung, 18-20 September, 1996, Delhi.

${ }^{1}$ For study on labour rights violations, see APFOL (1996). 
The internal hostilities and mistrust has greatly weakened the labour movement in Pakistan. Despite 50 years of their existence and the related work, the trade unions have miserably failed to respond effectively and collectively to the challenges confronting them and the society.

The labour market situation is also being affected by the existence of widespread prevalence of "child labour." Children, at times as small as being 5 to 6 years of age, are found working in numerous work places, a number of their activities carry considerable occupational and health hazards. And this is besides the fact that these children are denied their very fundamental right of the "childhood" i.e. to have sufficient time to play and rest, and existing facility for the education.

Finally, labour market is expected to be seriously affected by the pursuit of free trade regime coinciding with the policies of privatisation and structural adjustments. These set of policies, importantly, are being pursued without taking adequate safeguards and doing greater homework. They carry considerable risk of severely affecting domestic manufacturing, and employment and labour market conditions.

This paper makes an attempt to further elaborate these points and concerns in seven sections. This has been done in such a way that Section II discusses the existing situation of employment and unemployment. The issue of underemployment and poverty is discussed in Section III. Working conditions appear in Section IV, while child labour is briefly discussed in Section V. The other issues such as unions and labour laws are briefly touched in Section VI. The concluding remarks appear in Section VII.

\section{EMPLOYMENT AND UNEMPLOYMENT}

\section{Labour Force and Participation Rates}

The labour force in Pakistan was estimated to be $34.74 \mathrm{Mn}$. in 1993-94, see Table 1. A relatively smaller labour force, however, is due to the fact that crude activity rate of the labour force is as low as 27.9 percent, see Table 2. Hence, the potential for a rise in activity rate and the size of labour force does exist should the phenomenon of “discouraged workers' hypothesis" especially prevailing amongst females subside and their participation is accurately accounted. The participation rate for males falling in the age-group of 24-54 years, however, is more than 94 percent.

It is also important to point out that children are also active in the labour market. As high as 16.8 percent of the boys and 6.9 percent of girls of the age-group

\footnotetext{
${ }^{2}$ However, there have been many efforts in the past to forge unity and a recent such initiative is the formation of Pakistan Workers' Confederation (PWC) by the leading national centres. Presently there are 8 affiliates of the PWC, namely: APFTU, BLF, APFOL, MLF, PTUF, FOBFIE, APTUF and APTUO.
} 
Table 1

Civilian Labour Force in 1993-94

\begin{tabular}{lr} 
& \\
\hline Labour Force & 34.73 \\
Employed & 33.05 \\
Unemployed & 1.68 \\
\hline
\end{tabular}

Source: FBS (1994).

Table 2

Age-specific Participation Rate in 1993-94

\begin{tabular}{cccc} 
& & & (Percent) \\
\hline Age-groups & Both Sex & Male & Female \\
\hline $10-14$ & 12.3 & 16.8 & 6.9 \\
$15-19$ & 33.4 & 52.3 & 12.1 \\
$20-24$ & 47.8 & 84.9 & 14.0 \\
$25-29$ & 52.7 & 96.7 & 14.4 \\
$30-34$ & 54.6 & 98.5 & 17.1 \\
$35-39$ & 57.3 & 98.5 & 16.2 \\
$40-44$ & 58.2 & 97.9 & 18.2 \\
$45-49$ & 59.7 & 97.5 & 17.8 \\
$50-54$ & 58.8 & 94.2 & 17.1 \\
$55-59$ & 54.8 & 91.8 & 15.1 \\
60 and Above & 40.0 & 62.0 & 10.0 \\
All & 27.9 & 45.7 & 8.9 \\
\hline
\end{tabular}

Source: FBS (1994).

of 10-14 participate in the labour. ${ }^{3}$ The participation rate rises substantially for the children in the age-group of 15-19 years. Half of the boys and over one-tenth of girls of this age group are active in the labour market. This is an area of serious concern, and is discussed subsequently in this paper as well.

\section{The Employed}

Pakistan's labour market is essentially informal in nature, see Table 3. Selfemployed and unpaid family helpers account for about two-thirds of the employed. This proportion rises to three-fourths in case of female employment. The consideration on generating additional employment opportunities for women should

${ }^{3}$ It is, however, important to point out that participation rate for the children in the age-group 1014 raises to 14.91 percent in the child labour survey conducted by the Federal Bureau of Statistics, and for the males it becomes as high as 22.53 percent. See FBS (1996)/Table 3. 
Table 3

Employment Status by Sex in 1993-94

\begin{tabular}{lccc} 
& & & (Percent) \\
\hline Employment Status & Both Sex & Male & Female \\
\hline Employer & 1.0 & 1.2 & 0.2 \\
Self-employed & 41.9 & 46.3 & 15.6 \\
Unpaid Family Helper & 23.8 & 17.6 & 60.1 \\
Employee & 33.3 & 34.9 & 24.1 \\
\hline
\end{tabular}

Source: FBS (1994).

need to focus on this reality. According to the labour force survey, 1993-94, a majority of unemployed women have indicated preference for such work opportunities [FBS (1994)].

The sectoral employment, seen in the historical perspective points out some worrying features of the labour market, see Table 4. The agricultural sector employment, after declining over the years, has started increasing marginally in recent years. And this is coinciding with a significant decline in the share of manufacturing sector employment. These signals point towards a worsening of the labour market situation. Only sector showing greater growth in employment has been the construction sector. Although trade and others have also been increasing their share in employment.

\section{Unemployment}

The rate of open unemployment as can be calculated from Table 1 is around 5 percent. It is interesting to point out that the least unemployment, 1.5 percent-2.3 percent, is found in the age-group of 30-49 years, while the highest, 10.6 percent, is prevailing amongst children in the age group of 10-14 years and is no less either, 8.3 percent for the children in the age-group of 15-19 years, see Table 5. Further distressing is to note that 8.6 percent of the senior citizens, 60 years and above, are found unemployed. Further, unemployment rate in this age group is as high as 27.1 percent for the women. This clearly indicates non-availability of: any formal social security and/or a source of livelihood for the senior citizens, and the fast diminishing traditional social safety networks available earlier in the form of families, kinships, friends and even local communities. Females are more vulnerable than the males, while 3.9 percent of the males are unemployed. It is important to point out that the rate of unemployment is 10 percent for females and is 14.0 percent and 11.9 percent respectively for the children of 10-14 and 15-19 years of age-group.

According to the Labour Force Survey 1993-94, slightly over a-quarter the unemployed had an earlier work experience in the manufacturing sector mainly as 
Table 4

Sectoral Employment in Historical Perspective

\begin{tabular}{|c|c|c|c|c|c|c|c|}
\hline Year & Agriculture & $\begin{array}{l}\text { Manuf. } \\
\text { Mining }\end{array}$ & Construction & $\begin{array}{c}\text { Electr. and Gas } \\
\text { Distribution }\end{array}$ & Transport & Trade & Others \\
\hline 1960s & 57.95 & 14.75 & 2.64 & 0.36 & 3.49 & 9.05 & 11.90 \\
\hline $1970 \mathrm{~s}$ & 54.82 & 14.03 & 4.22 & 0.53 & 4.81 & 10.84 & 10.73 \\
\hline $1980 \mathrm{~s}$ & 51.70 & 13.51 & 5.57 & 0.76 & 4.83 & 11.77 & 11.86 \\
\hline $1989-90$ & 51.15 & 12.84 & 6.38 & 0.59 & 4.89 & 11.93 & 12.22 \\
\hline 1990-91 & 47.45 & 12.38 & 6.62 & 0.83 & 5.24 & 13.24 & 15.22 \\
\hline 1991-92 & 48.27 & 12.53 & 6.33 & 0.79 & 5.51 & 13.10 & 13.48 \\
\hline 1992-93 & 47.54 & 10.89 & 6.94 & 0.85 & 5.52 & 13.31 & 14.95 \\
\hline $1993-94$ & 50.04 & 10.12 & 6.50 & - & 4.95 & 12.78 & 15.56 \\
\hline 1994-95 & 50.04 & 10.12 & 6.50 & - & 4.95 & 12.78 & 15.56 \\
\hline $1995-96$ & 50.04 & 10.12 & 6.50 & - & 4.95 & 12.78 & 15.56 \\
\hline
\end{tabular}

Source: Government of Pakistan (1996). 
Table 5

Unemployment Rate by Age and Sex - 1993-94

\begin{tabular}{cccc}
\hline Age-groups & Both Sex & Male & Female \\
\hline $10-14$ & 10.6 & 9.4 & 14.0 \\
$15-19$ & 9.0 & 8.5 & 11.9 \\
$20-24$ & 6.7 & 6.3 & 9.1 \\
$25-29$ & 3.4 & 2.8 & 6.6 \\
$30-34$ & 2.0 & 1.4 & 5.2 \\
$35-39$ & 1.5 & 1.0 & 4.1 \\
$40-44$ & 2.1 & 1.1 & 7.2 \\
$45-49$ & 2.3 & 1.8 & 5.3 \\
$50-54$ & 4.2 & 2.3 & 16.2 \\
$55-59$ & 4.5 & 2.2 & 19.1 \\
60 and Above & 8.6 & 6.4 & 27.1 \\
All & 4.8 & 3.9 & 10.0 \\
\hline
\end{tabular}

Source: FBS (1994).

"production workers". The process of privatisation and free-trade regime being pursued can be identified as important contributing factors. A-quarter were also engaged in the community, social and personal services [FBS (1994)].

\section{UNDEREMPLOYMENT AND POVERTY}

The agricultural sector continues to be the main source of employment despite its declining contribution in the GDP, see Table 6. Further, the land ownership pattern is highly skewed. In all, there are $5.07 \mathrm{Mn}$. farms commanding an area of 19 Mn. hectares. Out of this $15.61 \mathrm{Mn}$. hectares are cultivated by $17.5 \mathrm{Mn}$. agricultural workers. However, a-quarter of the cultivated area is owned by just $0.1 \mathrm{Mn}$. farmers. While as many as $2.4 \mathrm{Mn}$. farmers own 11 percent of the farm area which is also comprised of as high as 47 percent of the total farms. The size of all these farms is less than 2 hectare. ${ }^{4}$ The situation of tenants and owners-cum-tenants is not very much dissimilar either. On average, there is 0.89 hectare of land being operated by an agricultural worker. Such a highly skewed land ownership pattern is then: (i) leading to uneconomic land holdings, and (ii) generating extremely low income for a large proportion of the workers engaged in the agricultural sector.

The existing pattern and status of employment has led to a situation, whereby a-quarter of the employed find their employment income meeting half of the subsistence requirements. And another quarter barely manage to meet the subsistence

${ }^{4}$ For details, see Government of Pakistan (1996). 
Table 6

Share of Selected Sectors in GDP

\begin{tabular}{|c|c|c|c|c|c|}
\hline Year & Agriculture & Manufacturing & Construction & $\begin{array}{c}\text { Wholesale and Retail } \\
\text { Trade }\end{array}$ & $\begin{array}{c}\text { Transport, Storage and } \\
\text { Communication }\end{array}$ \\
\hline $1989-90$ & 25.8 & 17.6 & 4.1 & 16.5 & 9.5 \\
\hline 1990-91 & 27.7 & 17.7 & 4.1 & 16.5 & 9.6 \\
\hline 1991-92 & 26.1 & 17.8 & 4.1 & 16.4 & 9.8 \\
\hline 1992-93 & 24.2 & 18.3 & 4.2 & 16.5 & 10.2 \\
\hline $1993-94$ & 24.3 & 18.4 & 4.1 & 16.3 & 10.2 \\
\hline 1994-95 (R) & 24.7 & 18.2 & 4.0 & 16.2 & 10.0 \\
\hline $1996-96(\mathrm{P})$ & 24.8 & 18.0 & 3.9 & 16.5 & 9.8 \\
\hline
\end{tabular}

Source: Government of Pakistan (1996).

Note: "R" indicates Revised and "P" indicates Provisional. 
requirements through their employment income. ${ }^{5}$ The proportion of population living below poverty line, on the basis of calorie intake, is a-quarter, see Table 7 . During the period 1984-85 to 1990-91, the poverty level first declined and then increased. It is, however, important to point out that the level of poverty increases substantially, if a different definition is used. Two-fifths of the population is estimated to be living below poverty line, if the basis of calculation is the basic needs.

Table 7

Trends in Poverty in Pakistan

Percentage of Population Below Poverty Line

\begin{tabular}{lcccccc}
\hline & \multicolumn{3}{c}{ On the Basis of Calorie Intake } & & \multicolumn{2}{c}{ On the Basis of Basic Needs } \\
\cline { 2 - 4 } Area & $1984-85$ & $1987-88$ & $1990-91$ & & $1987-88$ & $1990-91$ \\
\hline Overall & 25.20 & 24.36 & 25.32 & & 35.69 & 40.57 \\
Rural & 30.92 & 30.48 & 30.88 & & 44.77 & 56.26 \\
Urban & 23.64 & 23.88 & 24.12 & & 32.88 & 32.50 \\
\hline
\end{tabular}

Source: FBS (1995).

Lesser remunerative work is yet another dimension of the labour market in Pakistan. Of all those, who were enumerated as employees by the labour force survey of 1993-94, as high as 42.13 percent were drawing a monthly income of less than Rs 1500. While 36.39 percent of the employees were drawing a monthly income in the range of Rs 1501-2500. The average income of the employees was Rs 2036 and it was significantly lower for females, Rs 1381 [LFS (1994), p. 379]. These levels of employment income clearly point towards the marginalised conditions of a large proportion of the employees and consequently the prevalence of poverty conditions.

The informal sector is the largest source of urban employment. However, this sector is confronted with the twin menace, namely: low remunerative employment and extremely poor working conditions. The average monthly income of the informal sector participant, except for the self employed is in the range of Rs 11841729, see Table 8. Notwithstanding the lower wage of the employees of different categories in

Table 8

Average Monthly Wages in the Informal Sector

\begin{tabular}{lccccc}
\hline Sector & Self-employed & Family Helpers & Regular Workers & Casual Workers & Shagirds \\
\hline Manufacturing & 7691 & 1583 & 1651 & 1682 & 589 \\
Services & 2997 & 1729 & 1249 & 1610 & 435 \\
Trade & 4622 & 1312 & 1219 & 1184 & 448 \\
Transport & 5159 & 2254 & 1685 & 1407 & 495 \\
Total & 5675 & 1573 & 1633 & 1577 & 566 \\
\hline
\end{tabular}

Source: Kemal and Mahmood (1993), pp. 111-112.

${ }^{5}$ For details, see NMC (1989, 1989a). 
the informal sector, the self-employed earn as high as Rs 7691 and excepting activities following under services, their monthly income exceeds Rs 5150. The deplorable part of the informal sector is the poor wage of "Shagirds," (apprentices). Their average monthly wages vary from Rs 435 to Rs 589.

There, however, does not seem to be significant difference in the monthly wages of family helpers, regular workers and casual workers. Notwithstanding, the absence of any significant differences, the fact remains that poor remuneration is the major characteristics of the informal sector.

\section{WORKING CONDITIONS}

Lack of adequate safe-guards is the major characteristics of numerous work places in Pakistan. Even the organised sector is found to be no exception to this sorry state of affairs. The textile sector, for instance, which demonstrates the largest manufacturing activity in Pakistan, is known to display poor and even hazardous working conditions. ${ }^{6}$ Notwithstanding this serious lack, yet another dimension of the labour market issue in Pakistan is the longer working hours. One-third of the employed in Pakistan are found to be working for 56 and above hours a week, see Table 9. While as high as 74 percent of the employed are working for more than 41 hours a week, this percentage raises to 82.6 for the employed in the urban areas. These longer working hours in the backdrop of lesser remunerations and poor working conditions are important labour market issues.

Table 9

Distribution of Weekly Hours of Work in 1992-93

\begin{tabular}{lccc}
\hline & \multicolumn{3}{c}{ (Percent) } \\
\cline { 2 - 4 } Weekly Hours & All & Urban & Rural \\
\hline Less than 15 & 1.2 & 0.8 & 1.4 \\
15-24 & 4.3 & 2.2 & 5.0 \\
$26-34$ & 7.4 & 3.8 & 8.6 \\
$35-41$ & 12.8 & 10.1 & 13.7 \\
$42-48$ & 30.7 & 39.5 & 27.5 \\
$49-55$ & 10.5 & 9.7 & 10.8 \\
56 and Above & 32.8 & 33.5 & 32.6 \\
Total & 100.0 & 100.0 & 100.0 \\
\hline
\end{tabular}

Source: FBS (1993).

${ }^{6}$ The large-scale textile mills are found grossly lacking in providing proper and safer working conditions. For details, see Ghayur and Zar (1993). 
The informal sector appears to be supreme in terms of also offering poor working conditions. Measures aiming at occupational health and safety are grossly overlooked in this sector. In addition, this sector is known for longer working hours, stretching far beyond the normal hours of work and those prescribed under the labour laws. ${ }^{7}$ The average weekly hours of work in the manufacturing, service, trade and transport range between 49.33-91.51, see Table 10. The longer working hours run across the ownership and employment status. The casual workers are found to be working relatively longer than others. The most distressing point of the longer working hours relate to the participants of the transport sector. The casual workers are found to be working for more than 91 hours a week. Except "Shagirds" (apprentices), all of the employed are found working for more than 57 hours a week. This is in gross violation of the law, which stipulates far less working hours for transport workers and that too with a mandatory rest of half an hour after four hours of work.

Table 10

Average Hours of Work Per Week in the Informal Sector

\begin{tabular}{lccccc}
\hline Sector & $\begin{array}{c}\text { Head of the } \\
\text { Enterprise }\end{array}$ & $\begin{array}{c}\text { Family } \\
\text { Helper }\end{array}$ & $\begin{array}{c}\text { Full Time } \\
\text { Worker }\end{array}$ & $\begin{array}{c}\text { Casual } \\
\text { Worker }\end{array}$ & Shagird \\
\hline Manufacturing & 55.62 & 64.12 & 57.04 & 56.48 & 57.15 \\
Services & 60.54 & 56.78 & 52.03 & 49.33 & 41.03 \\
Trade & 63.33 & 52.18 & 63.37 & 65.83 & 44.67 \\
Transport & 67.21 & 57.15 & 62.78 & 91.51 & 35.33 \\
Total & 58.89 & 60.99 & 57.05 & 64.45 & 55.15 \\
\hline
\end{tabular}

Source: Kemal and Mahmood (1993) p. 69.

\section{CHILD LABOUR}

Childhood is a formative age and should be spent on activities and environments conducive for the development and growth of human mind and body. These environments can be ensured by the existence of and an easy access to education and training academies, and availability of sufficient time to play and rest. In Pakistan, according to the child labour survey, 14.91 percent and 2.66 percent of children respectively in the age group of 10-14 and 5-9 years are active in the labour market. Alternatively, 3.3 Mn. children have been estimated to be working in numerous work places and activities [FBS (1996)]. These figures though lower than the one quoted for Pakistan, however, are based on the only scientifically designed

\footnotetext{
${ }^{7}$ For a discussion on practices and functioning of the informal sector, see Kemal and Mahmood (1993); Chaudhary et al. (1989) and Ghayur (1993). And for a review of labour laws, see Ghayur (1996) and Ghayur and Zar (1993).
} 
sample survey of some 12,000 households. ${ }^{8}$ Notwithstanding the lower figures yielded by this survey, the mere existence of child labour is a matter of some serious concerns. Besides denying the childhood to children, further distressing is the fact that children are confronted with long working hours, and poor, harsh and exploitative working conditions. This is nothing but sheer cruelty meted out to the children. $^{9}$

The industrial classification of these children, according to the child labour survey, is such that two-thirds of them work in the agricultural sector. Further threefourths of them were in rural areas and are unpaid family helpers, while a three-fifths of those working in urban areas are employees, mainly engaged in the informal sector [FBS (1996)].

The major concentration of child labour in urban areas is found in the smallscale activities largely falling in the informal sector. In the informal sector, children are found to be working for 50-62 hours a week, see Table 11. Small and tender age when found working and that too under harsh and exploitative conditions does indicate an area of serious concern in the Pakistani labour market. Yet another disappointing aspect of the child labour is their remunerations. Except trade, their wages are half of the full-time workers engaged in the informal sector [Kemal and Mahmood (1993), p. 727].

Table 11

Average Hours of Work Per Week in the Informal Sector

\begin{tabular}{lccc}
\hline Sector & Child Labour & Full Time Workers & Shagirds \\
\hline Manufacturing & 54.7 & 57.0 & 57.2 \\
Services & 50.0 & 52.0 & 41.0 \\
Trade & 59.1 & 63.4 & 44.7 \\
Transport & 62.0 & 62.8 & 35.3 \\
\hline
\end{tabular}

Source: Kemal and Mahmood (1993) p. 72.

\section{OTHER ISSUES}

\section{Divided and Fragmented Trade Unions}

Divided and fragmented trade unions, incapable to respond to the challenges, are also responsible for the labour market issues in Pakistan. The deplorable situation of the trade unions can be gauged by the fact that there are less than 2,000 collective bargaining agents (CBAs) in Pakistan, while the registered trade unions

${ }^{8}$ For a study of different figures quoted on child labour, see ILO (1992).

${ }^{9}$ For a discussion on the issue of child labour, see Ghayur (1995a, 1996a); Kemal (1994); ILO (1992) and FBS (1996). 
are more than 7,000, see Table 12. This shows multiplicity of unions at an enterprise. The polarisation of the unions can also be seen by the fact that average membership of a union was 1,880 in 1951 and it declined to a meagre 135 in 1990. The situation is aggravated further by the fact that hundreds of trade union federations and national centres exist, while ideally there should have been one representative body of the workers.

Table 12

Evolution of Trade Unionism

\begin{tabular}{lcccc}
\hline Year & $\begin{array}{c}\text { Registered } \\
\text { Unions }\end{array}$ & $\begin{array}{c}\text { Declared } \\
\text { Members }\end{array}$ & $\begin{array}{c}\text { Average } \\
\text { Membership }\end{array}$ & $\begin{array}{c}\text { Organised Non-agr. } \\
\text { Labour Force }\end{array}$ \\
\hline 1951 & 209 & 393,137 & 1,880 & \\
1955 & 474 & 325,610 & 690 & \\
1960 & 708 & 350,604 & 500 & \\
1965 & 965 & 512,225 & 530 & \\
1970 & 2,522 & 735,620 & 290 & $6.7 \%$ \\
1975 & 8,196 & 694,667 & 80 & $5.8 \%$ \\
1980 & 6,551 & 869,128 & 130 & $6.5 \%$ \\
1985 & 6,170 & 859,770 & 135 & $6.0 \%$ \\
1990 & 7,027 & 951,990 & 135 & $6.3 \%$ \\
\hline
\end{tabular}

Source: ICFTU (1995) p. 7.

Responsive and responsible unions and unionism certainly do not exist. Hence, the trade unions have not made any significant contribution towards bringing improvements in working and labour market conditions. Neither, it has been able to contribute, as an active member of the civil society, towards the debate and efforts seeking resolution of socio-economic problems confronting Pakistan. ${ }^{10}$

\section{Inadequate Labour Laws Insufficiently Implemented}

Pakistan inherited a number of labour laws at the time of independence. They have been updated over the years to respond to the emerging needs of the economy and labour market. Some new have also been made. Presently, the labour laws are dealing with: working conditions, hours of work, wages, occupational health and safety, social security, workers' welfare, old age benefits, industrial relations, child and bonded labour, etc. ${ }^{11}$ Notwithstanding the vastness of the existing laws, they are

\footnotetext{
${ }^{10}$ For a discussion on the trade unions, see Ghayur (1996).

${ }^{11}$ Some details appear in Ghayur and Zar (1993) and Ghayur (1996a).
} 
considered inadequate. Firstly, their coverage is restricted to those who are employed in the organised sector. Secondly, the basic right to organise and to do collective bargaining is available to a fraction of the organised sector work force. Thirdly, the existing laws allow for contract labour. Fourthly, the laws dealing with industrial relations promote multiplicity of unions and federations. Lastly, the laws also affect industrial peace by allowing outsiders at the plant level unions. Further, the workers in the informal sector and agricultural sector simply do not fall under the purview of labour laws.

Yet another dimension of the labour laws is their inadequate implementation. Besides the complicated nature of many of them, thus affecting understanding and implementation, the employers in connivance with the officials of the concerned departments make successful attempts to put their implementation in abeyance. Such a practice then denies the legal benefits to workers and, importantly, every effort is made to delay the formation of trade unions.

\section{CONCLUDING REMARKS}

The economy of Pakistan is not able to absorb productively the labour force and all indications point towards a worsening of labour market conditions in the future. And those employed, a significant proportion of them are confronted with poor working conditions at times carrying occupational health and safety hazards. Further, employment income is barely enough to meet half of the subsistence requirements of a-quarter of the employed.

Such employment conditions force other members of the family to become active in the labour market on any wage, and terms and conditions. Consequently, the malpractice of child labour is also flourishing. The working children are confronted with harsh working conditions. They also receive significantly less wages. Further, they are also being denied of their fundamental right to childhood and education.

The existing labour laws aiming at the protection of the rights of workers and to promote their welfare are inadequately implemented. Yet another problem is the tactics used by the employers. In number of cases they, in connivance with the officials of the concerned departments, make successful efforts to deny the legal rights to workers. Thus, effecting savings at the cost of the welfare and poor working conditions of workers. At times, the government sector is also found responsible for such denials. Of particular concern is the denial to workers of their fundamental right to form association and do the collective bargaining. This situation, to a certain extent, is also attributable to a divided and fragmented trade union movement in Pakistan.

The labour market conditions may aggravate further on account of the free trade regime being pursued. Incidentally, this process is coexisting with the programme of structural adjustments being undertaken at the behest of donors. Of 
particular concern is the: (i) substantial rise in the prices of utilities, (ii) opening up of the economy without taking adequate safeguards and taking the private sector and the workers into confidence, and (iii) the large-scale privatisation of the state owned enterprises. Some caution and adequate home work is the need of the hour. Further, this process needs to be slowed down and should accompany: (i) evolving of social safety nets, (ii) designing of a comprehensive Employment Promotion and Manpower Development policy with a simultaneous focus on short-term target oriented employment schemes, (iii) effecting improvements and enlarging activities in the fields of R\&D and S\&T, and (iv) improving labour laws as well as their implementation.

\section{REFERENCES}

APFOL (1996) Working Conditions in the Hattar Industrial Estate (NWFP). A Study of Neglect and Exploitation. Rawalpindi: All Pakistan Federation of Labour.

Chaudhary, Muhammad Ali, Pervez Azeem and Abid Aman Burki (1989) Skill Generation and Entrepreneurship Development under "Ustad-Shagird" System in Pakistan. Islamabad: A Study Sponsored and Supervised by the Friedrich-EbertStiftung for the National Manpower Commission.

FBS (1994) Labour Force Survey, 1993-94. Islamabad: Federal Bureau of Statistics.

FBS (1995) Income Inequality and Rural Poverty in Pakistan, 1990-91. Islamabad:

Federal Bureau of Statistics.

FBS (1996) Summary of Results of Child Labour Survey, 1996 Islamabad: Federal Bureau of Statistics. (Unpublished.)

Ghayur, Sabur (1993) (ed) The Informal Sector of Pakistan: Problems and Policies. Islamabad: Friedrich-Ebert-Stiftung. (The Informal Sector Study No.3.)

Ghayur, Sabur (1995) Employment and Under-employment in Pakistan: Existing Situation, Problems and Suggestions for Tackling the Issue. Journal of Rural Development and Administration 27:2.

Ghayur, Sabur (1995a) Child Labour: Nature, Concerns, Reasons and Measures for Elimination. Paper presented in the International Seminar on "Poverty Alleviation", organised by the Institute of Policy Studies, Friedrich-EbertStiftung and Islamic Development Bank, 16-17 December. Islamabad

Ghayur, Sabur (1996) Trade Unions, Democracy and Development in Pakistan. .Karachi: PILER/FES.

Ghayur, Sabur (1996a) Labour Issues in Pakistan. Islamabad: Friedrich-EbertStiftung.

Ghayur, Sabur, and Zulekha Zar (1993) Pakistan: Working Conditions in the Textile Sector. Islamabad: Friedrich-Ebert-Stiftung.

Pakistan, Government of (1993) The 8th Five-Year Plan. Islamabad: Planning Commission. 
Pakistan, Government of (1996) Pakistan Economic Survey, 1995-96. Islamabad: Economic Advisor's Wing. Ministry of Finance.

ICFTU (1995) Trade Unions Rights and Industrial Relations in Pakistan. Paper presented in the Conference on "Structural Adjustment and Trade Union Rights," organised by ICFTU and Pakistan Council of ICFTU. 15-17 October. Rawalpindi

ILO (1992) World Labour Report. Geneva: International Labour Organisation.

Kemal, A. R. (1994) Child Labour in Pakistan. Paper presented in the National Workshop on Elimination of Child Labour, organised jointly by the Directorate of Workers' Education, UNICEF and FES in April, Islamabad.

Kemal, A. R. and Zafar Mahmood (1993) Labour Absorption in the Informal Sector and Economic Growth in Pakistan. Islamabad: Friedrich-Ebert-Stiftung. (Informal Sector Study No.2.)

NMC (1989) Unemployment and Underemployment in Pakistan: A Review of the Past. Islamabad: National Manpower Commission. (NMC Study No.3.)

NMC (1989a) Report of the National Manpower Commission. Islamabad: National Manpower Commission.

Pak/GD (1994). The Labour Force Situation Report. Pak/Netherlands Project on "Human Resource." Growth Dynamics University/Ministry of Labour, Manpower and Overseas Pakistanis. Roterdam/Islamabad. 